\title{
Determination of the Opinions of Prospective Science Teachers About Biology Lessons Taught Through Distance Education
}

\author{
Emrah Ö̈bŭgutu (Assistant Professor) \\ Faculty of Education, Siirt University, Turkey
}

Doi:10.19044/ejes.v8no2a1

URL:http://dx.doi.org/10.19044/ejes.v8no2a1

Submitted: 03 February 2021

Accepted: 28 April 2021

Published: 30 June 2021
Copyright 2021 Author(s)

Under Creative Commons BY-NC-ND 4.0 OPEN ACCESS

\begin{abstract}
This paper aims to determine the opinions of prospective teachers about biology lessons conducted through distance education during the pandemic. In the study, the focus group study technique was applied as one of the qualitative research methods. 15 prospective teachers from the Department of Science Education, studying in the $2^{\text {nd }}, 3^{\text {rd }}$, and $4^{\text {th }}$-grades in Siirt University, participated in this study. Questions were presented to the prospective teachers in the form of a semi-structured form and interviews were conducted separately for each grade and recorded. The data collected were analyzed via content analysis. Based on the findings of the study, the prospective teachers stated that they had internet-related and technical problems and they also failed to follow biology lessons due to their unsuitable home environment and ineffective communication processes. It was understood that the vast majority of prospective teachers preferred face-to-face evaluation rather than e-evaluation. To make biology lessons more efficient, it was recommended that prospective teachers should be obliged to attend classes, YouTube videos and animations should be added, classroom or laboratory lessons should be organized, WhatsApp groups should be created and question section should be added through these groups, and lessons should be synchronous rather than asynchronous.
\end{abstract}

Keywords: Biology lessons, synchronous lessons, asynchronous lessons, distance education, face-to-face education

\section{Introduction}

Since December 29, 2019, the world is faced with the threat of a virus thought to break out in China. Following the rapid spread of this virus that has turned into a global pandemic affecting the whole world, regulations have been made regarding travel bans, quarantine, and extraordinary measures to reduce the rate of spread of the pandemic and ensure social distancing. However, the pandemic had a significant influence on many fields including education in particular (Üstün \& Özçiftçi, 2020; Genç \& Gümrükçüoğlu 2020). In parallel with its effects on schools and the education system, educational environments have been reformulated and, thus, distance education has been the leading environment.

Distance education refers to all education and training activities carried out to increase the relationship and communication between students, teachers, and teaching-related documents with the help of information and communication technologies (ICT). It can be defined as a system based 
on the principle of student self-learning which aims to bring preconditions and limits to access to educational environments (Allen \& Seaman, 2013; Yüksekdağ, 2020). Based on this definition, distance education can be considered as one of the measures taken in terms of activities related to education and training.

Considering the processing of internet-based distance education, what stands out is information exchange between students and teachers. During the implementation stage, lessons can be conducted in two ways: synchronous and asynchronous. While synchronous education allows teachers and students to communicate in different ways, it also provides the opportunity to create an environment of face-to-face education. However, it is not a requirement for anyone involved in face-to-face education to be present in the same environment (Çetin \& Özdemir, 2018a). Asynchronous education provides the learner with the opportunity of individual learning independent from the teacher (Karatepe, Küçükgençay \& Peker, 2020). Asynchronous learning also contributes to the learning of students by uploading the necessary documents related to the lesson and the lecture as video recording if necessary.

It is a known fact that distance education avails lifelong learning, individual development, and the national economy. However, education and training activities may be interrupted from time to time, causing failure to reach the expected success. To improve this success, teaching activities must be carried out effectively (Çetin \& Özdemir, 2018b). In this process, although students benefit from the educational opportunity remotely and without the need to go to school, they receive an education without face-to-face interaction, group work, classroom activities, and social development. Students and institutions mainly face problems regarding the implementation stage (Çı̆̆lık \& Bayrak, 2015).

Biology is an important subject in science and will continue to be. Therefore, more attention should be paid to biology in terms of scientific lesson planning. This is because the current position of biology, especially the issues in genetics, biotechnology and ecology, has reached such a level that it can help humanity much more than expected (Kiziroğlu, 1988).

\section{Objective}

The fall term program of science teaching involves biology-related lessons such as Biology II, Environmental Education, Social Effects of Gene Technology, and Genetics and Biotechnology lessons, as elective courses in the previous curriculum. Researches show that the main focus is on the evaluation of the opinions of prospective teachers regarding distance education. Hence, this study has been designed to determine the opinions of prospective science teachers related to distance education of the above-mentioned lessons during the pandemic. Since there are no studies on biology lessons tought with distance education subject in the literature, this research is supposed to be of capital importance.

\section{Method}

As the opinions of prospective science teachers about biology lessons conducted with distance education were examined, the focus group technique, which is one of the qualitative research methods, was used. The aim of this technique is to obtain in-depth, detailed, and multidimensional qualitative information about the participants' perspectives, experiences, interests, experiences, tendencies, thoughts, perceptions, feelings, attitudes, and habits in relation to a certain subject (Tanhan, 2017). 


\section{Research Sample}

Prospective teachers are the students studying at education faculties to be a teacher after graduation in Turkey. This study was carried out with 15 prospective science teachers enrolled in the 2nd, 3rd, and 4th grades of the Science Teaching Department of Siirt University who take biology-related lessons. Participants were determined via simple random sampling techniques.

Table 1. Grade levels, lessons, and number of prospective teachers

\begin{tabular}{lll}
\hline Grade levels & $\begin{array}{l}\text { Number of } \\
\text { prospective teachers }\end{array}$ & Lessons \\
\hline $2^{\text {nd }}$-grade & $5(3 \mathrm{~F}-2 \mathrm{M})^{*}$ & Biology 2 \\
\hline $3^{\text {rd }}$-grade & $5(3 \mathrm{~F}-2 \mathrm{M})^{*}$ & $\begin{array}{l}\text { Environmental } \\
\text { Education }\end{array}$ \\
\hline $4^{\mathrm{th}}$-grade & $5(3 \mathrm{~F}-2 \mathrm{M})^{*}$ & $\begin{array}{l}\text { Social Effects of Gene } \\
\text { Technology }\end{array}$ \\
& & \\
$*(3 \mathrm{~F}-2 \mathrm{M})$ means, there are 3 females and 2 Males Prospective Science \\
Teachers.
\end{tabular}

Grade levels, lessons, and number of prospective teachers are shown in Table 1.Five (5) prospective teachers from each grade participated in the interviews. Totally, nine (9) of the participants were male and six (6) were female.

\section{Data Collection Tool and Data Collection}

The focus group interview technique, in which interview questions were in the form of a semi-structured interview form, was used in this study. Prior to the main interview, the pilot scheme of the study was carried out along with measures taken for the problems that might arise during the actual implementation. The same number of prospective teachers participated in the pilot interview. After the pilot scheme, the number of questions, which was 11 in the semistructured interview form, was rearranged and was reduced to 6 . During the actual implementation, prospective teachers were informed about the purpose of the study and asked to answer the questions sincerely and correctly. As in the pilot scheme, the interviews were made via the zoom program and recorded. These interviews were conducted separately for each grade level. The last interview was made with 5 prospective teachers from the 2 nd-grade, 5 prospective teachers from the 3rd-grade, and 5 prospective teachers from the 4 th-grade. Each meeting took an average of 1 hour 20 minutes.

During the focus interview, prospective teachers were asked the following questions in a semi-structured format:

1. What are the positive and negative aspects of teaching biology lessons with distance education?

2. To what extent and how have your note-taking habits and studying methods changed in relation to biology lessons during distance education?

3. How has the exams through distance education affected your preparation for the exam of the biology lesson?

4. In relation to the evaluation of the exams, would you prefer e-evaluation or face-to-face evaluation? Why?

5. Which of the biology lessons have you found more efficient: synchronous or asynchronous? Why?

6. What are your recommendations for more efficient lessons regarding biology lessons during 
distance education?

\section{Data Analysis}

While interviewing the prospective teachers, small interventions were made to ensure participants give more answers. The answers recorded via the Zoom program were converted into a written document. Focus group interview data were analyzed descriptively along with content analysis. A descriptive analysis approach was also used in the study. In the descriptive analysis approach, data can be summarized and interpreted according to pre-determined themes. Furthermore, the data can be arranged according to the themes that emerge in the analysis of the research questions or by considering the interview questions (Yıldırım \& Şimşek, 2008; Baş \& Akturan, 2008; Cab1, 2016).

The reliability of the study was determined by comparing the number of agreement and disagreement. Also, it was calculated using Miles and Huberman's (1994) Reliability = agreement/(agreement + disagreement) $* 100$ formula. Agreement among coders is expected to be at least $80 \%$. The study is reliable as an agreement of $88 \%(71 / 71+10) * 100$ was reached among the coders in the study (Bakioğlu \& Çevik, 2020). In a study where descriptive analysis is used, it is important for the sake of validity to express the statements of individuals whose opinions are directly quoted and to explain the results based on them (Y1ldirım \& Şimşek, 2008). To ensure validity, direct quotations were included and the data were interpreted. Direct quotations were made from the answers given by the prospective teachers to indicate the expressions of the question. On the other hand, prospective teachers were numbered with the grade level (2.S, 3.S , 4.S). The number given to the prospective teachers (Ö1-Ö2-Ö3...) as grade means "sınıf" and prospective teachers means "öğrenci" in Turkish.

\section{Findings}

In the study, the findings obtained as a result of the analysis of the data collected from the semi-structured interview form were presented to the prospective teacher in turn. Firstly, the prospective teachers were asked, "What are the positive and negative aspects of teaching biology lessons with distance education?". The frequency distribution of the findings regarding the answers given is shown in Table 2 below.

Table 2. Opinions of prospective teachers regarding positive and

\begin{tabular}{llll}
\multicolumn{4}{l}{ negative aspects of biology lessons during distance education } \\
\hline Positive Aspects & $\mathrm{f}$ & Negative Aspects & $\mathrm{f}$ \\
\hline $\begin{array}{l}\text { No compulsory } \\
\text { attendance }\end{array}$ & 3 & $\begin{array}{l}\text { Internet-and- } \\
\text { technical problems }\end{array}$ & 9 \\
$\begin{array}{l}\text { Video recording } \\
\text { and being able to } \\
\text { watch again }\end{array}$ & 3 & $\begin{array}{l}\text { The home } \\
\text { environment being } \\
\text { inconvenient }\end{array}$ & 6 \\
$\begin{array}{l}\text { Using technology } \\
\text { better }\end{array}$ & 2 & $\begin{array}{l}\text { Being unable to } \\
\text { ask questions } \\
\text { Extreme comfort } \\
\text { and laziness }\end{array}$ & 3 \\
$\begin{array}{l}\text { Uploading PDF } \\
\text { and documents }\end{array}$ & 2 & 3 &
\end{tabular}




\begin{tabular}{|c|c|c|c|}
\hline & & No lab & 3 \\
\hline \multirow[t]{4}{*}{ Saving time } & 1 & $\begin{array}{l}\text { No feedback and } \\
\text { correction }\end{array}$ & 2 \\
\hline & & Inefficient & 2 \\
\hline & & Boring videos & 1 \\
\hline & & $\begin{array}{l}\text { Poor } \\
\text { communication }\end{array}$ & 1 \\
\hline Total & 11 & & 30 \\
\hline
\end{tabular}

Table 2 reveals that in line with the answers, $30(73.2 \%)$ and $11(26.8 \%)$ of the prospective teachers stated their opinions about the negative and positive aspects, respectively.

Considering the negative opinions, they stated that they mostly experience internet-related problems, such as internet disconnections and technical problems. As a result, they are not able to follow the lessons due to inconvenience at home and frequent guests, and they have to spare time for housework. In addition, they also stated that they are unable to easily ask the lecturer questions like in the classroom environment, resulting to a poor feedback system and lack of correction. Furthermore, there is no effective and healthy communication. Failure to benefit from the laboratory facilities especially in relation to the Biology II lesson and related problems, extreme comfort and laziness as well as boring and inefficient lessons were also enumerated as negative aspects.

Among the most positive opinions are the non-necessity of attendance, the opportunity of saving videos and watching them over and over again, learning how to use technology better thanks to distance education, as well as benefiting from uploaded and downloadable PDFs and documents related to the biology lesson and spending more time on biology lessons.

Some statements of the prospective teachers regarding the relevant category are as follows: $I$ think it is negative since I have problems with the internet. Also, if education were face to face, the only thing I would do would be to go to school, but now I have a lot of different things to do. I have time-related problems as well, no positive aspects. (2.S-Ö1)

I think it would be more efficient if it was face to face. The anatomy lesson should be taught in the classroom, but circumstances did not allow it. If it was in the classroom, we would be able to visually examine the muscles, bones, organs, and body structures, but I was negatively affected by this situation. (3.S-Ö2)

I think I fell behind because of technical problems or because I couldn't attend the class when guests came home. This situation made it difficult to follow the lesson (gene technology and society). (4.S-Ö3)

Secondly, the prospective teachers were asked the question: "To what extent and how have your note-taking habits and studying methods changed in relation to biology lessons during distance education?". The frequency distribution of the findings regarding the answers given is shown in Table 3 below.

Table 3. Opinions of prospective teachers regarding changes in note-taking habits and studying methods 


\begin{tabular}{llllll}
\hline Face to Face & Frequency & Distance Education & Frequency & $\begin{array}{l}\text { No } \\
\text { Change }\end{array}$ & Frequency \\
\hline $\begin{array}{l}\text { I was studying by } \\
\text { taking notes }\end{array}$ & 7 & I do not take notes & 6 & $\begin{array}{l}\text { No } \\
\text { change }\end{array}$ & 3 \\
$\begin{array}{l}\text { I was studying } \\
\text { harder }\end{array}$ & 2 & $\begin{array}{l}\text { I study via PDF } \\
\text { documents }\end{array}$ & 3 & \\
$\begin{array}{l}\text { I was studying by } \\
\text { writing }\end{array}$ & 1 & I do not study as before & 2 & \\
$\begin{array}{l}\text { I was revising } \\
\text { books }\end{array}$ & 1 & $\begin{array}{l}\text { I study by watching } \\
\text { videos }\end{array}$ & 2 & \\
$\begin{array}{l}\text { I was reviewing } \\
\text { the subjects }\end{array}$ & 1 & $\begin{array}{l}\text { I study harder than } \\
\text { before }\end{array}$ & 1 & \\
& & I study only for exams & 1 & \\
& & I do not study at all & 1 & \\
& & $\begin{array}{l}\text { I take notes if I hardly } \\
\text { understand subjects }\end{array}$ & 1 &
\end{tabular}

Table 3 reveals that most of the prospective teachers stated that they study by taking notes while some used to study harder by writing during face-to-face education. Besides, one of them stated that s/he made up his deficiencies by revising books, while another one of them studied by reviewing subjects. On the other hand, during distance education, 6 prospective teachers stated that they no longer take notes, while some prospective teachers study via PDFs and by watching videos. Finally, one of them stated that s/he studies only for exams or does not work at all, studies more than before, and takes notes if subjects are hardly understood. follows:

Some of the statements of prospective teachers regarding the relevant category are as

Since I know more or less the subjects of Biology II, I do not take any extra notes. There was no change in my studying style. I study now just as I studied in the previous Biology I lesson. (2S-Ö4)

I am currently taking notes as well because the anatomy lesson is based on rote learning, at which I am bad, I cannot learn the lesson without taking notes. Not much has changed for me. (3S-Ö1)

Since we were in the classroom before, I was also taking notes during all the lessons related to biology lessons (Genetics, Anatomy, Environmental Education, and Biology I-II) and I could also review the topic. I am currently not doing it, and I cannot study because I am in quarantine. (4S-Ö2)

Thirdly, the prospective teachers were asked, "How has the exams with distance education affected your preparation for the exam of the biology lesson?". The frequency distribution of the findings regarding the answers given is shown in Table 4 below. 
Table 4. Frequency distribution of prospective teachers' opinions on the exams of the biology lesson during distance education

\begin{tabular}{llll}
\hline Face-to-face Education & $\mathrm{f}$ & Distance Education & $\mathrm{f}$ \\
\hline I was well-prepared for the lesson & 55 & PDF and video & 5 \\
$\begin{array}{l}\text { I studied more } \\
\text { I elaborated on subjects }\end{array}$ & 4 & $\begin{array}{l}\text { I studied less and was more } \\
\text { comfortable }\end{array}$ & 4 \\
$\begin{array}{l}\text { I studied the course book } \\
\text { I summarized subjects }\end{array}$ & 2 & I studied only on exam day & 2 \\
$\begin{array}{l}\text { I studied based on notes I took during } \\
\text { the lesson }\end{array}$ & 1 & I did not study at all & 2 \\
\end{tabular}

Table 4 shows that during face-to-face education, prospective teachers studied long before the exam and harder, while some of them studied more detail based on the course book. Besides, it has been observed that one student studied through summarization while another one studied

based through note taking. On the other hand, during distance education, a majority of the prospective teachers studied through PDFs and videos and were more comfortable but studied less. In addition, some prospective teachers stated that they only study on exam day and benefit from the internet and books during the exam, while some did not study at all or studied harder.

Some of the statements of prospective teachers regarding the relevant category are as follows:

I was studying by summarizing during face-to-face education. I have been studying for Biology I by summarizing the subjects of the previous semester, but this semester I did not summarize subjects but studied from the PDFs uploaded to the system. (2S-Ö1)

I was negatively affected as I could not study due to housework and lack of enough time for both Anatomy and other lessons. At the same time, I had difficulty preparing for the exam because there were children at home. I would have studied better if I could be provided with face-to-face education. (3S-Ö2)

I never studied for the exam of gene technology and society during distance education. I used to study for the exams of the biology-related lessons long before taking the exams. (4S-Ö1)

Fourthly, the prospective teachers were asked, "In relation to the evaluation of the exams, would you prefer e-evaluation or face-to-face evaluation? Why?". The frequency distribution of the findings regarding the answers given is shown in Table 5.

Table 5. The frequencies of student opinions regarding the e-evaluation and face-toface evaluation of the exams

\begin{tabular}{llll} 
E-evaluation & Frequency & Face to face & Frequency \\
\hline High grades & 4 & Fairer & 5 \\
Too much & 2 & We answered & 5 \\
homework & & questions in exams & \\
\hline
\end{tabular}




\begin{tabular}{|c|c|c|c|}
\hline & & on our own & \\
\hline I am stressed & 2 & $\begin{array}{l}\text { Not that easy to pass } \\
\text { exams }\end{array}$ & 2 \\
\hline \multirow{3}{*}{$\begin{array}{l}\text { I had difficulty } \\
\text { uploading the } \\
\text { answer sheet }\end{array}$} & 2 & $\begin{array}{l}\text { More sensitive } \\
\text { evaluation }\end{array}$ & 2 \\
\hline & & $\begin{array}{l}\text { We knew what we } \\
\text { learned }\end{array}$ & 2 \\
\hline & & $\begin{array}{l}\text { We were able to } \\
\text { provide missing } \\
\text { information }\end{array}$ & 1 \\
\hline
\end{tabular}

Table 5 reveals that most of the prospective teachers prefer face-to-face evaluation with only three prospective teachers stating that they prefer e-evaluation to get higher grades in exams.

Others stated that they are subjected to too much homework, stress, or problems regarding uploading. They further added that face-to-face evaluations allow them to answer the questions of exams without the assistance of others and that exams would not be that easy to pass with a better method of evaluation to ensure they understand what they learn and provide the missing information. follows:

Some of the statements of prospective teachers regarding the relevant category are as

A face-to-face evaluation would be better. Exams as I believe it would allow us to at least take the exam with our own knowledge. (2S-ÖI)

I would prefer face to face as I believe the face-to-face evaluation is fairer, which is why everyone is responsible for his or her answers. Yet e-evaluation made it easier for us to get higher grades. (3S-10̈)

I would prefer a face-to-face evaluation in all lessons, not just in this lesson (gene technology and society). I think it would be fairer. I wish we could do an internship and get our scores based on that. (4S-Ö1)

I do not believe that e-evaluation is efficient. Those who attend classes and those who do not attend get roughly the same score, so I don't think it's fair. We got higher scores by studying less, so I would prefer e-evaluation. (4S-Ö5)

Fourthly, the prospective teachers were asked, "Which of the lessons have you found more efficient: synchronous or asynchronous? Why?". The frequency distribution of the findings regarding the answers given is shown in Table 6.

Table 6. Prospective teachers' opinions on synchronous or asynchronous methods used in biology lessons

\begin{tabular}{llll}
\hline Asynchronous & Frequency & Synchronous & Frequency \\
\hline $\begin{array}{l}\text { Time- } \\
\text { independent }\end{array}$ & 5 & $\begin{array}{l}\text { Question and } \\
\text { answer, feedback, } \\
\text { discussion, } \\
\text { communication } \\
\text { Waste of time }\end{array}$ & 8 \\
$\begin{array}{l}\text { Easier to study } \\
\text { for exams }\end{array}$ & 2 & More efficient & 2 \\
Fewer technical & 1 & & \\
\hline
\end{tabular}


problems

failure to participate 2

Little information 1

Active participation 1

Distractibility

Table 6 reveals that being time-independent is what makes asynchronous lessons mainly advantageous apart from being easier to study for exams and having fewer technical problems. Participants find asynchronous lessons better in terms of some advantages such as question and answer, discussion, or better communication. The disadvantage is that they found such lessons to be inefficient or a waste of time. follows:

Some of the statements of prospective teachers regarding the relevant category are as

Having a discussion environment in synchronous lessons enhanced my adaptation. I think that learning is more permanent even though there is little information in synchronous lessons. (2S- ̈̈2)

I have a hard time studying for the exam (Biology II) in synchronous lessons. Studying for the exam is easier in asynchronous lessons, but synchronous lessons are more efficient. (2S-Ö3)

I think that asynchronous lessons are better. I have the advantage of watching whenever I want because it is independent of time. $(4 S-\ddot{O} 2)$

Finally, the prospective teachers were asked "What are your recommendations for more efficient lessons regarding biology lessons during distance education?". The frequency distribution of the findings regarding the answers given is shown in Table 7.

Table 7. Suggestions for more efficient biology lessons during distance education

\begin{tabular}{|c|c|c|c|}
\hline Suggestions & Frequency & Suggestions & Frequency \\
\hline $\begin{array}{l}\text { Technical infrastructure } \\
\text { and conditions should be } \\
\text { improved }\end{array}$ & 4 & $\begin{array}{l}\text { There should be } \\
\text { WhatsApp groups and } \\
\text { question-solving hours }\end{array}$ & 2 \\
\hline Compulsory attendance & 2 & $\begin{array}{l}\text { Lessons should be } \\
\text { synchronous }\end{array}$ & 1 \\
\hline $\begin{array}{l}\text { Video and animation } \\
\text { should be added }\end{array}$ & 2 & $\begin{array}{l}\text { Tablet computers should } \\
\text { be distributed }\end{array}$ & 1 \\
\hline $\begin{array}{l}\text { Additional marks can be } \\
\text { given to attendees }\end{array}$ & 2 & $\begin{array}{l}\text { The time of the lesson } \\
\text { should be appropriate }\end{array}$ & 1 \\
\hline Internet support & 2 & Weekly homework & 1 \\
\hline $\begin{array}{l}\text { The number of PDFs and } \\
\text { documents can be } \\
\text { increased }\end{array}$ & 2 & Meetings should be held & 1 \\
\hline $\begin{array}{l}\text { Lessons can be taught in a } \\
\text { classroom or lab }\end{array}$ & 2 & & \\
\hline
\end{tabular}

Table 7 reveals that there is a consensus among the participants related to the improvement of technical infrastructure and conditions, compulsory attendance, additional YouTube videos and 
animations, and an increase in the number of PDFs and other documents. It shows that biology lessons should be taught in classrooms or labs, WhatsApp groups should be created along with question-solving hours, lessons should be synchronous with an appropriate schedule, weekly homework should be assigned, and meetings should be periodically held with prospective teachers.

Some of the statements of prospective teachers regarding the relevant category are as follows:

In order to ensure the permanent and meaningful learning of the Biology II lesson, weekly homework may be given by being uploaded to the system at specified times. (2S-Ö1)

The application phase of the Biology II lesson, which is related to the biology laboratory, can be given in the biology laboratory through distance learning, or the experiments and applications related to the subject can be conducted in this way. (2S-Ö2)

I do not believe that distance education will ever replace the school. I lost my hope; if the student conditions are improved, the solution can be provided by imposing compulsory attendance. It is also good for increasing students' motivation. (4S-Ö1)

More PDFs and documents should be added to the system. In addition, tablets were distributed to schools other than the university and thus, tablets can be distributed to us as well. (4S-Ö5)

\section{Conclusion}

This study took into consideration the opinions of prospective teachers about the biology lesson taught during distance education. The opinions were taken from various aspects regarding the biology lessons conducted with distance education. Determining the positive and negative aspects of the system and how the habits of studying and taking notes on biology during the pandemic process have changed, as well as the changes in prospective teachers' style of studying for the exam of the lesson and the positive and negative aspects of e-evaluation, play a crucial role in identifying the advantages and disadvantages of asynchronous or synchronous. Such a study may also be crucial in terms of suggesting solution that future teachers should set to ensure biology lessons that have to be taught with distance education are more efficient. The ideas and opinions put forward may also help shape and improve the system, the biology lesson, and other lessons. Thus, it would help to enhance the efficiency of the process.

In this study, prospective teachers were asked 6 questions in total through a semi-structured form, and the interviews were recorded on zoom along with a content analysis made according to the answers. First of all, they were asked "What are the positive and negative aspects of teaching biology lessons with distance education?". In line with the responses, it was understood that they mostly experienced internet-related problems, could not log into the system due to technical problems or ask the instructor questions as though they are in a classroom environment, and were also deprived of the necessary feedback and correction due to poor communication. One may also notice that they could not benefit from the laboratory facilities especially in relation to the Biology

II lesson. Furthermore, they are likely to experience problems in the future due to lack of studies in laboratories. In addition, they feel comfortable and become lazy since an already difficult lesson like biology is boring and inefficient. On the other hand, the fact that there was a requirement of attending lessons was regarded as a positive side of distance education. Similarly, they stated that it is advantageous to save videos into the system and watch them over and over again, to learn the technology through distance education, to have uploaded PDFs and documents related to biology lessons that may be useful in the future, and to be able to download these documents at any time. The general advantages of online courses are ease of use, flexibility, and convenience (Harris, 
Hardy, Agunloye Hearrington,2014). Additionally, Eygü and Karaman (2013) suggested that the models used in distance education impose more responsibility for learning than classical education models. Also, distance education is more effective in learning to ensure prospective teachers reach their desired goals. Additionally, distance education has some advantages for students who cannot access traditional face to face courses while maintaining direct contact with faculty, increased student mastery of course content, provided the ability to ask questions in real time, and increased student engagement (Viola, Saeki \& Hendricker, 2019). In this study porospective teachers mainly concerns the challenges of the distance education simlar to a previous research (Song, Singleton, Hill \& Hwa Koh, 2004), the results indicated that numerous disadvantages for fully online courses, including limited interaction with other students and faculty, feelings of isolation, difficulty maintaining motivation and self-discipline, and a perception of a lower quality of instruction.

Secondly, prospective teachers were asked, "To what extent and how have your notetaking habits and studying methods changed in relation to biology lessons during distance education?". It was understood from the responses that the studying systems of the prospective teachers have completely changed. Female prospective teachers spend a lot of time on housework and male prospective teachers cannot find the opportunity to study as much as they used to as they help their families. It has been determined that some prospective teachers sometimes feel hopeless, lose hope, and do not study as before. Also, some prospective teachers do not take notes in both biology and other lessons or do not study at all, and they miss days when they ought to study hard and attend school.

Thirdly, prospective teachers were asked, "How has the exams with distance education affected your preparation for the exam of the biology lesson?". It is understood from the responses that during face-to-face education, they studied long before exams and harder, in detail and from the course book or through summarization and note-taking. On the other hand, some of them study less or did not study at all. Besides, the styles and habits regarding studying for the biology lesson seem to have changed, and as a result of an incorrect evaluation of exams, statements such as "We easily pass exams as subjects are mainly those we have already learned throughout face-to-face education" reveal that prospective teachers do not feel obliged to study at all. A possible reason for this situation has been associated with exams being considered as perfunctory and lacking the ability to be determinative (Eroğlu \& Kalayc1, 2020).

Fourthly, the prospective teachers were asked, "In relation to the evaluation of the exams, would you prefer e-evaluation or face-to-face evaluation? Why?". A majority of the participants preferred face-to-face education, while 3 participants preferred distance education for getting higher marks. The prospective teachers expressed that they have much homework, get stressed, and have problems when uploading documents to the system during e-evaluation. Regarding the face-to-face evaluation, the prospective teachers stated that it would be fairer if there were a face-to-face evaluation. This is because they believe that it would solve the questions of exams without any help, it would not be so easy to pass, the measurement would be more precise, they would learn what they know and do not know, and they will satisfy a need. Başaran, Doğan, Karaoğlu, and Şahin (2020) found that the questions faced by prospective teachers, who do not have the habit of self-study or the ability to do so, outweigh in the distance education system.

Fifthly, the prospective teachers were asked, "Which of the biology lessons have you found more efficient: synchronous or asynchronous? Why?". A majority of the participants agree that though some technical issues occur, lessons should be synchronous for reasons including question and answer sessions, feedback, discussion, and effective communication. Similarly, Çakır and Arslan (2020) found that the synchronous classroom environment is more beneficial, adding that 
synchronous classroom lessons are important though technical problems occur occasionally. Additionally, Wagner, Enders, and Pirie (2016) discussed best practices for incorporating live or synchronous video conferences into an online course. However, in literature there are some studies that mentions the appropriate interactions could be supplied between students and instructors by distance educational environments (Cho \& Kim, 2013; Fedynich, Bradley, \& Bradley, 2015).

Finally, the prospective teachers were asked, "What are your recommendations for more efficient lessons regarding biology lessons during distance education?". A majority of the participants agreed that the technical infrastructure and conditions should be improved. For a better process and higher satisfaction, compulsory attendance should be imposed, additional YouTube videos and animations should be added, the number of PDFs and other documents should be increased, biology lessons should be taught in classrooms or labs, WhatsApp groups should be created along with question-solving hours, lessons should be synchronous with an appropriate schedule, weekly homework should be assigned, and meetings should be periodically held with prospective teachers. They also agreed that these recommendations would improve students' motivations towards the lesson. This result is also supported by other studies in the literature (Goulımarıs, 2015; Aytaç, 2020).

\section{Recommendations}

Lessons should be taught more synchronously to increase participation. Therefore, it is important to ensure student-teacher interaction especially in lessons based on rote learning and in lessons that are difficult to understand certain subjects like biology. In addition, it is important to hold meetings with prospective teachers at certain periods, to create WhatsApp and similar groups, and to solve questions related to biology lessons, if any, to ensure communication with prospective teachers. Similar to the recommendation, Park (2013) highlights the features of many instructional technologies, along with examples of how these can be incorporated into coursework.

Regarding biology lessons given asynchronously or synchronously, it is thought that adding more visual media applications, videos, and animations to the system will increase the permanence and concretize the learning environment. It is also vital to teach biology lessons as if they are being lectured in the classroom and to teach the laboratory-related lessons as much as possible by means of experiments in the laboratory.

Most of the prospective teachers complain about technical problems. Thus, developing the technical infrastructure is among the primary works that should be done to enhance the efficiency of the lessons. In addition, an internet package should be given to students to increase their participation in classes, as in EBA (Education Information Network).

Based on the results obtained in the research, the recommendations for future researches are as follows:

1. The opinions of prospective teachers about other lessons or field lessons should be taken into consideration.

2. The data related to the subject were collected through a semi-structured interview form via zoom. By increasing the number of participants, data can be collected with the help of a questionnaire along with a quantitative evaluation.

3. Similar studies can be done with prospective teachers studying in different departments. 


\section{References}

Aytaç, T. (2020). The problems and opinions of school administrators during COVID-19 pandemic: A qualitative study from Turkey. European Journal of Educational Sciences, 7 (4), 5779.

Bakioğlu, B. \& Çevik, M. (2020). COVID-19 pandemisi sürecinde fen bilimleri öğretmenlerinin uzaktan eğitime ilişkin görüşleri. [Science teachers' Views on distance education in the COVID19 pandemic process.] Turkish Studies, 15(4), 109-129.

Başaran, M., Doğan, E., Karaoğlu, E. \& Şahin, E. (2020). Koronavirüs (covid-19) pandemi sürecinin getirisi olan uzaktan eğitimin etkililiği üzerine bir çalışma. [A study on effectiveness of distance education, as a return of coronavirus (covid-19) pandemic process.] Academia Journal of Educational Research 5(2), 368-397.

Cabı, E. (2016). Uzaktan eğitimde e-değerlendirme üzerine öğrenci algıları. [The Perception of students on E-Assessment in distance education.] Journal of Higher Education \& Science.Volume:6 Number:1 94-101.

Cho, M. H., \& Kim, B. J. (2013). Students' self-regulation for interaction with others in online learning environments. The Internet and Higher Education, 17(1), 69-75. doi:10.1016/j. iheduc.2012.11.001

Çakır, R. \& Arslan, F. (2020). Uzaktan eğitim öğrencilerinin eş zamanlı sanal sınıf ortamlarını kullanım niyetleri ile uzaktan eğitime ilişkin tutumlarının incelenmesi. [Investigation of distance education students' intention to use synchronous virtual classroom environments and their attitudes towards distance education] International Journal of Turkish Educational Studies, 8 (15), 114-133.

Çetin, A. \& Özdemir, Ö.F. (2018a). Mode-method interaction: the role of teaching methods on the effect of instructional modes on achievements, science process skills, and attitudes towards physics, Eurasia J. Math. Sci. Technol. Educ., 14 (5), 1815-1826.

Çetin, A. \& Özdemir, Ö. F. (2018b). Harmanlanmış ve yüz-yüze öğrenme ortamlarında kullanılan öğretim yöntemlerinin internete yönelik tutuma etkisi. [The effects of teaching methods in blended and face-to-face instructional media on attitudes towards internet] Abant İzzet Baysal Üniversitesi Eğitim Fakültesi Dergisi, 18 (3), 1378-1403.

Çığlık, H. \& Bayrak, M. (2015). Uzaktan öğrenme ve yapısalcı yaklaşım, [Distance learning and constructivist approach], IJODE, 1(1): 87-102.

Eroğlu, F. \& Kalaycı, N. (2020). Üniversitelerdeki zorunlu ortak derslerden Türk Dili dersinin uzaktan ve yüz yüze eğitim uygulamalarının karşılaştırılarak değerlendirilmesi. [Comparative evaluation of the distance and Face-to-face education practices in the required Turkish language course at universities] Journal of Mother Tongue Education 8(3), 1001-1027.

Eygü, H. \& Karaman, S. (2013). Uzaktan eğitim öğrencilerinin memnuniyet algıları üzerine bir araştırma. [A study on the satisfaction perceptions of the distance education students]. Kırıkkale University Journal of Social Sciences Volume:3 Number 1. 36-59.

Fedynich, L., Bradley, K. S., \& Bradley, J. (2015). Graduate students' perceptions of online learning. Research in Higher Education Journal, 27, 1-13.

Genç, M.F. \& Gümrükçüoğlu, S. (2020). Koronavirüs (covıd-19) sürecinde ilâhiyat fakültesi öğrencilerinin uzaktan eğitime bakışları [The views of theology faculty students on distance education in the coronavirus (Covid-19) process] Turkish Studies, 15(4), 403-422.

Gülen, S. \& Yaman, S. (2018). Fen Bilimleri dersinde argümantasyon süreci ve STEM disiplinlerinin kullanımı; Odak Grup Görüşmesi [Argumentation process and using stem disciplines in science course; focus group]. YYU Journal of Education Faculty, 15(1), 1184-1211. 
Goulımarıs, D. (2015). The Relationship Between Distance Education Students' Motivation and Saisfaction. Turkish Online Journal of Distance Education, 16(2), 13-27.

Harris, P., Hardy III, S., Agunloye, O., \& Hearrington, D. (2014). Perceptions of online versus faceto-face learning of educational leadership graduate students. European Journal of Educational Sciences, 1(4), 30-37.

Karatepe, F., Küçükgençay, N. \& Peker, B. (2020). Öğretmen adayları senkron uzaktan eğitime nasıl bakıyor? Bir anket çalışması. [What are the perspectives of teacher candidates on synchronous distance education? a survey study]. Journal of Social and Humanities Sciences Research (JSHSR) Vol: 7 Issue: 53 pp: 1262-1274.

Kiziroğlu, İ. (1988). Günümüzde biyoloji dersi ve amaçları. [Biologieunterricht heute und seine zielsetzungen] . Hacettepe University Journal of Education, (3): 243-250.

Özyürek, A., Begde, Z., Yavuz, F. \& Özkan, İ. (2016). Uzaktan eğitim uygulamasının öğrenci bakış açısına göre değerlendirilmesi. [Evaluation of distance education applications from students' perspective.] Karabuk University Journal of Institute of Social Science, 6 (2). 595-605.

Park, S. (2013). The potential of Web 2.0 tools to promote reading engagement in a general education course. TechTrends, 57(2), 46-53. doi:10.1007/s11528-013-0645-1.

Song, L., Singleton, E. S., Hill, J. R., \& Hwa Koh, M. (2004). Improving online learning: Student perceptions of useful and challenging characteristics. Internet and Higher Education, 7(1), 59-70. doi: 10.1016/j.iheduc.2003.11.003

Tanhan, F. (2017). Öğrencilerin kariyer seçimlerinde Aile ve sosyal medyanın etkisinin incelenmesi (Bir odak grup çalışması). [The examination of the effects of family and social media on students' career choices (a focus group work)] The Journal of Social Sciences Institute, Issue:35 177-190.

Üstün, Ç. \& Özçiftçi, S. (2020). COVID-19 Pandemisinin sosyal yaşam ve etik düzlem üzerine etkileri: Bir Değerlendirme Çalışması. [Effects of COVID-19 Pandemic on Social Life and Ethical Plane: An Evaluation Study.] Anatolian Clinic Journal of Medical Sciences, Volume 25, Supplement. 142-153.

Wagner, E., Enders, J., \& Pirie, M. (2016). Supporting academic integrity in a fully-online degree completion program through the use of synchronous video conferences. Journal of Informational Systems Education, 27(3), 159-173.

Viola, S., Saeki, E. \& Hendricker, E. (2019). Distance Education in Graduate Training Programs: Lessons Learned from School Psychology Students. Journal of Educators Online, 16 (2), Retrieved from https://www.thejeo.com/archive/2019_16_2 2/ viola_saeki hendricker.

Yıılırım, A. \& Şimşek, H. (2008). Sosyal Bilimlerde Nitel Araştırma Yöntemleri. (6. Baskı). Ankara: Seçkin Yayıncılık.

Yüksekdağ, B.B. (2020). Uzaktan hemşirelik eğitimine ilişkin algılar. [Perceptions on distance nursing education] Educational Tecnology Theroy and Practice Volume:10 Number 2. 490-503. 